IMF Country Reports $\quad 21 / 191$

\title{
Romania: Selected Issues
}




\section{INTERNATIONAL MONETARY FUND}

IMF Country Report No. 21/191

\section{ROMANIA}

\section{SELECTED ISSUES}

August 2021

This paper on Romania was prepared by a staff team of the International Monetary Fund as background documentation for the periodic consultation with the member country. It is based on the information available at the time it was completed on July 22, 2021.

Copies of this report are available to the public from

International Monetary Fund • Publication Services

PO Box $92780 \bullet$ Washington, D.C. 20090

Telephone: (202) 623-7430 • Fax: (202) 623-7201

E-mail: publications@imf.org Web: http://www.imf.org

Price: $\$ 18.00$ per printed copy

\section{International Monetary Fund Washington, D.C.}

(c) 2021 International Monetary Fund

CInternational Monetary Fund. Not for Redistribution 


\section{INTERNATIONAL MONETARY FUND}

\section{ROMANIA}

\section{SELECTED ISSUES}

July 22, 2021

\section{Approved By \\ European Department}

Prepared by Rudolfs Bems (EUR) and Mengxue Wang (FIN).

\section{CONTENTS}

CAN GOVERNANCE REFORMS LEAD TO HIGHER GROWTH IN ROMANIA? $\underline{3}$

A. Introduction $\underline{3}$

B. Methodologies $\underline{5}$

C. Main Regression Results and a Reform Scenario____ $\underline{7}$

D. The Role of the Investment Channel ____ $\underline{\underline{9}}$

E. Bridging the Infrastructure Gap ___

F. Conclusions and Policy Recommendations____

\section{FIGURES}

1. GDP per Capita Gaps with CEE Peers

2. Infrastructure Gaps with CEE Peers

3. Governance Gaps

4. Output Response to Governance Reforms ___

5. Governance and Output Catch-Ups_____ $\underline{8}$

6. Output Response to Government Effectiveness Reforms_____ $\underline{8}$

7. Output Response to Other Governance Subindices____

8. Investment Response to Governance Reforms ___ _

9. Output Response to Investment Shocks ___

10. Infrastructure Response to Governance Reforms ___ 13

11. Infrastructure Catch-Up with CEE Peers____ 14

\section{TABLES}

1. Regression Results for the Impact of Governance Reforms on Output____ $\underline{7}$

2. Regression Results for the Impact of Governance Reforms on Public Investment $\_\underline{10}$

3. Regression Results for the Impact of Governance Reforms on Private Investment_ 10

4. Regression Results for the Impact of Public Investment on Output 
5. Regression Results for the Impact of Private Investment on Output

6. Regression Results for the Impact of Governance Reforms on Infrastructure Index $\underline{14}$

\section{ANNEXES}

I. List of EM Countries and Data Sources $\underline{16}$

II. Definition of Worldwide Governance Index $\underline{18}$

III. Governance and Inequality

References $\underline{21}$ 


\section{CAN GOVERNANCE REFORMS LEAD TO HIGHER GROWTH IN ROMANIA?'}

Following significant improvements in governance in Romania during the EU accession period, limited progress was made over the last decade and large gaps with regional EU peers remain. This paper examines the potential impact of closing Romania's governance gaps could have on output. We find that a sustained governance reform effort could significantly boost medium-term growth prospects. Governance reforms could also increase investment and improve public infrastructure.

\section{A. Introduction}

1. Despite significant progress, sizable income and public infrastructure disparities with regional EU peers ${ }^{2}$ remain. Romania has been making steady progress over the last decade in terms of income convergence with EU peers (Figure 1). However, a persistent income gap remains, highlighting the need for continued and sustained efforts to catch up. Romania also exhibits sizable infrastructure gaps with EU peers. Looking at a broad set of infrastructure indicators, we conclude that Romania lags peers in all major categories of public infrastructure (Figure 2).

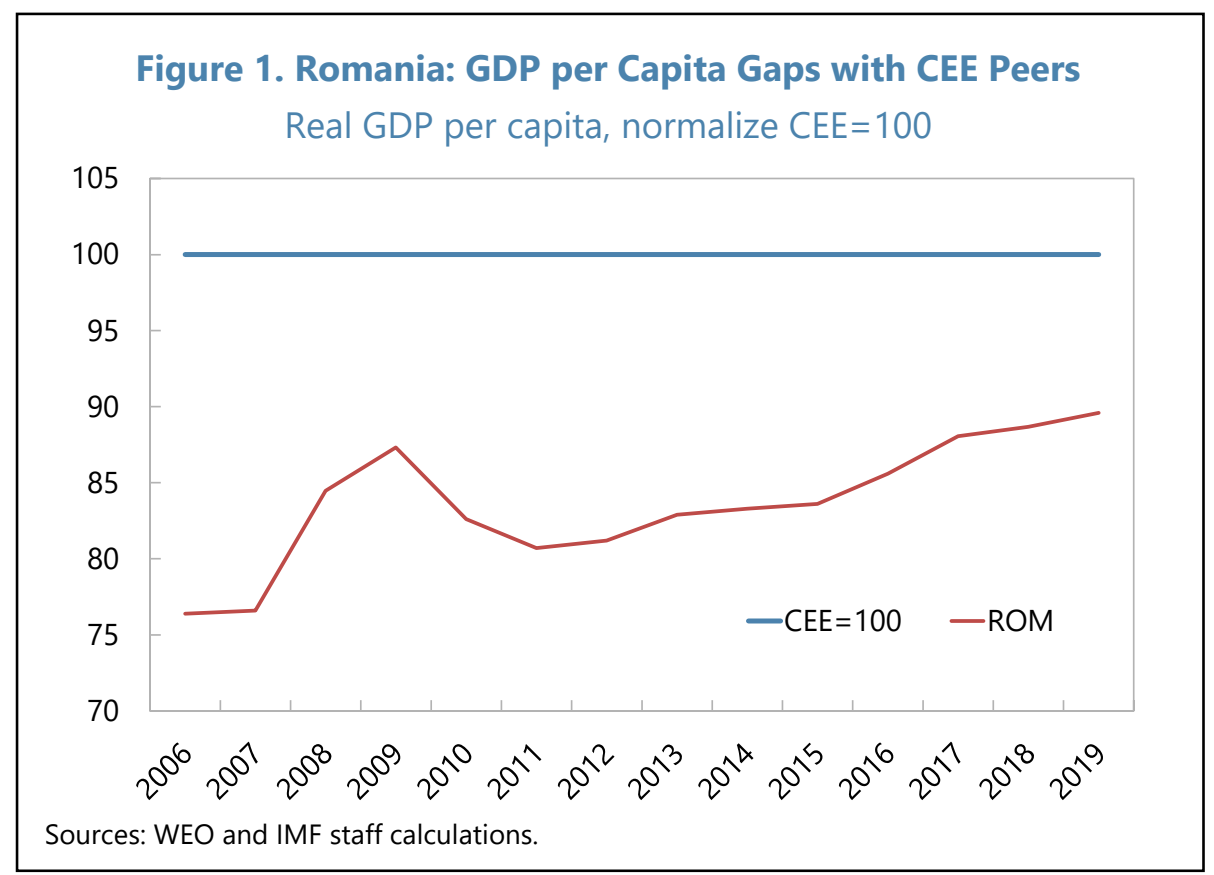

\footnotetext{
${ }^{1}$ Prepared by Rudolfs Bems and Mengxue Wang. We are grateful to seminar participants with the Romanian authorities, including the NBR and the Fiscal Council, for valuable comments and to Agnesa Zalezakova and Wei Zhao for assistance.

${ }^{2}$ Defined throughout the analysis as Bulgaria, Czech Rep., Estonia, Hungary, Latvia, Lithuania, Poland and Slovak Rep.
} 
Figure 2. Romania: Infrastructure Gaps with CEE Peers

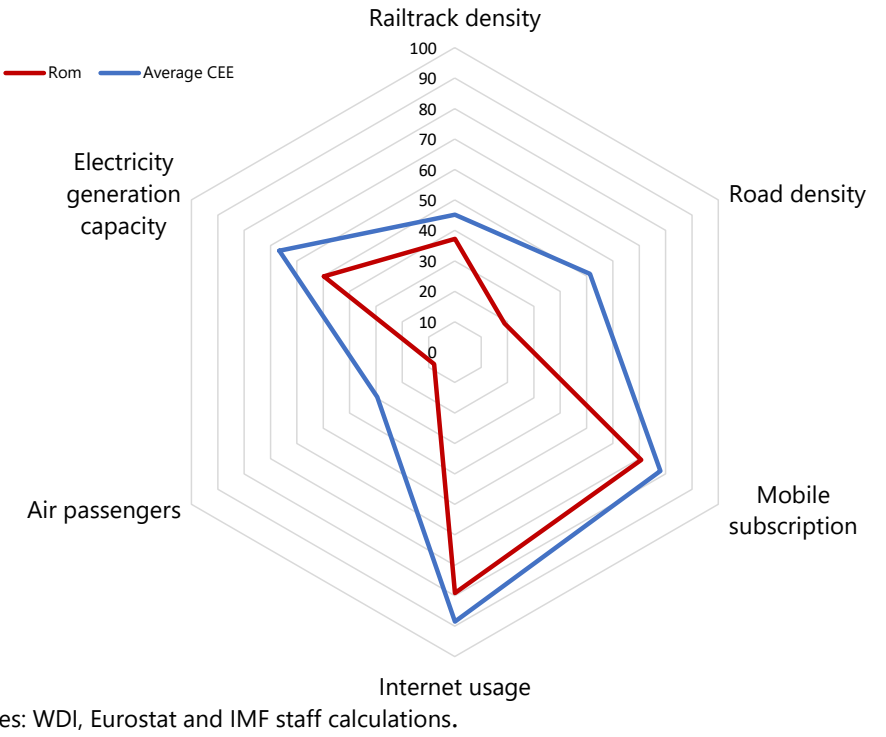

Sources: WDI, Eurostat and IMF staff calculations.

\section{At the same time, Romania has significant gaps in governance rankings when}

compared to EU regional peers. According to the Worldwide Governance Index (WGI) ${ }^{3}$, following significant advances in the fight against corruption and governance reforms during 2003-2010, around the EU accession period, limited progress was made over the last decade and even reversals in terms of the gap with regional peers in some areas, namely regulatory quality, control of corruption and government effectiveness, in recent years (Figure 3).

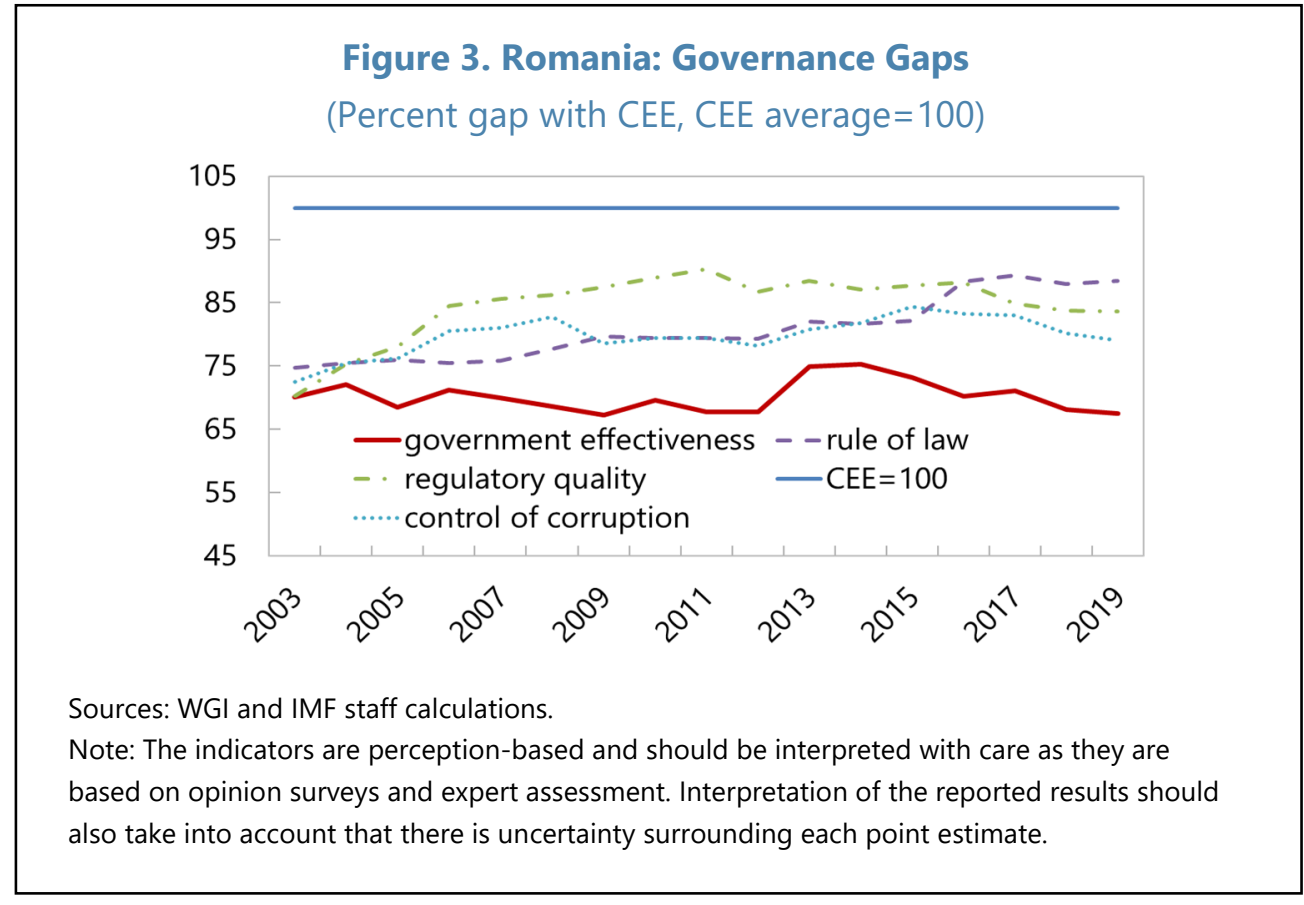

\footnotetext{
${ }^{3}$ See Annex II.
} 
3. This paper investigates the extent to which progress with governance reforms could provide a boost to Romania's output and public infrastructure. The paper uses panel data for emerging market (EM) economies to assess: (i) the potential impact of governance reforms on Romania's output growth, both the overall impact and the impact through the investment channel, and (ii) the potential impact of governance reforms on Romania's infrastructure stock. Would the infrastructure stock increase after governance reforms? Specific scenarios are examined to quantify the expected impacts.

\section{The economic impact of governance reform has been a topic of interest in the} economic literature and in policy circles. Our analysis leans heavily on the 2019 October WEO Chapter 3, which studies the impact of a broad range of structural reforms on economic outcomes and shows that governance improvements are the cornerstone of a successful structural reform agenda, boosting returns from other reforms. Our work is also related to the 2017 November EUR REO Chapter 2, which focuses on a specific component of governance-the rule of law-and its impact on economic outcomes. In this context, the 2019 April Fiscal Monitor Chapter 2 assesses the fiscal costs of corruption, another aspect of governance, showing that corruption is linked to reduced resource allocation to education and health spending, which can be detrimental to output growth. Our main contribution to the literature is to refine and update the literature's findings pertaining to the role of governance, its components, and the investment channel. In addition, we focus on a specific country application, constructing scenarios of the economic impact of feasible governance improvements, which can be readily applied to other emerging markets economies.

5. The rest of the paper presents the details of our analysis. Section $B$ reviews the methodologies used. Section $C$ presents the main regression results and examines a quantitative reform scenario for Romania. Section $D$ discusses our results pertaining to investment as a channel of transmission from governance reforms to output. Section E examines the impact of governance reforms on public infrastructure and section $\mathrm{F}$ concludes.

\section{B. Methodologies}

6. To quantify the impact of governance reforms, we consolidate the potential impacts of governance reforms into a production framework. In the production function, $Y=$ $\left.F\left(K^{p u b}, K^{p r i}, Z(\gamma)\right)\right)$, output is directly affected by public capital, private capital, and other production factors $Z(\gamma)$, including possible complementarity between public and private capital, where $\gamma$ represents the governance reforms. Public capital accumulation, $\delta K^{p u b}=G\left(I^{p u b}(\gamma), X(\gamma)\right)$, depends on new public investment, depreciation and other factors that affect the transformation from investment to capital. Similarly, the accumulation of private capital, $\delta K^{p r i}=G\left(I^{p r i}(\gamma), M(\gamma)\right)$, depends on new private investment, depreciation and other factors.

\section{The impact of governance reforms $(\gamma)$ drives the final output through both capital} accumulation and the production function. Governance reforms could increase the capital stock by raising investment directly or by affecting other factors in the capital accumulation equation, for example, investment efficiency etc. Governance reforms could also affect the final output through 
other factors, $Z(\gamma)$, besides the increase in capital. These factors could include higher productivity gains, the impact of complementarity between public and private capital, boosting labor market efficiency, and increasing financial market efficiency. We will explicitly quantify the impact through the investment channels and discuss the potential effects from other channels.

\section{We quantify the impact of governance reforms by using the local projection methods.}

Future changes in output and other macro variables are regressed on the change in the governance index

$$
y_{i, t+k}-y_{i, t-1}=c_{i}^{k}+d_{t}^{k}+\beta^{k} \text { GovReform }_{i, t}+\theta^{k} X_{i, t}+\epsilon_{i, t}^{k}
$$

where the GovReform $i, t$ is measured as the change in governance score from the WGI. We take the average of three WGI subindices-government effectiveness, rule of law and regulatory quality-to capture Romania's governance standings. ${ }^{4} y_{i, t+k}-y_{i, t-1}$ represents the k period ahead percentage change in the dependent variable of interest: output, public investment, private investment, or an index of the infrastructure stock. For example, if $y$ represents output, $y_{i, t+5}-y_{i, t-1}$ measures the percentage change in output five years after the governance shock compared to before the governance shock. Following 2019 October WEO Chapter 3, we add time and country fixed effects ( $d_{t}^{k}$ and $c_{i}^{k}$, respectively) and control for two lags of GDP growth, two lags of dependent variables and two lags of change in governance scores (with control variable $X_{i, t}$ ). The sample panel data covers up to 94 EMs during 1996-2015. ${ }^{5}$ The setup of the regression equation implicitly assumes that governance performance can affect the dependent variable (growth, investment, infrastructure and etc.) concurrently, while the dependent variable can induce changes in governance with a oneyear lag, capturing the more protracted nature of changes in governance.

\section{A similar empirical methodology is employed to trace out the role of the investment channel in propagating the economic impact of changes in governance. The influence of the} increase in investment (due to governance reform) on output is estimated as:

$$
y_{i, t+k}-y_{i, t-1}=c_{i}^{k}+d_{t}^{k}+\beta^{k} \operatorname{InvShock}_{i, t}+\theta^{k} X_{i, t}+\epsilon_{i, t}^{k}
$$

where, following Furceri and Li (2017), we identify exogenous investment shocks as the difference between each year's October WEO projections for investment in the current year and the actual observations for that year. The sample covers 78 EMs during 1991-2020. The rationale is that when the projection is carried out for the Oct WEO, almost all the information for the year has been incorporated and the remaining projection errors can be interpreted as purely exogenous movements in investment. $y_{i, t+k}-y_{i, t-1}$ is the $k$ period ahead change in output. The result of this

\footnotetext{
${ }^{4}$ The other three WGI subindices--voice and accountability, political stability, and control of corruption-are excluded because of their more limited relevance for the Funds' governance engagement framework (IMF 2018) and because corruption can be interpreted as a competing summary index of governance.

${ }^{5}$ Due to data limitations, the sample size decreases for regressions involving public and private investment (42 EMs over 1997-2015) or infrastructure index (32-42 EMs depending on projection horizons over 1996-2015). See Annex I for the full list of countries.
} 
regression also pins down the fiscal multiplier associated with public investment, which will be discussed later. All other variables in eq. (2) are identical to eq. (1).

\section{Main Regression Results and a Reform Scenario}

\section{Governance reforms have positive and significant impacts on output. Detailed} regression results for one through four-year changes after a two-standard-deviation shock in governance show an economically and statistically significant and persistent effect on output (see Table 1). The resulting output impulse response for up to 6 years after the shock reveals that the impact reaches its maximum two years after the shock, leading to a 2 percent increase in output level, and stabilizes at 1.5 percent six years after the shock (Figure 4).

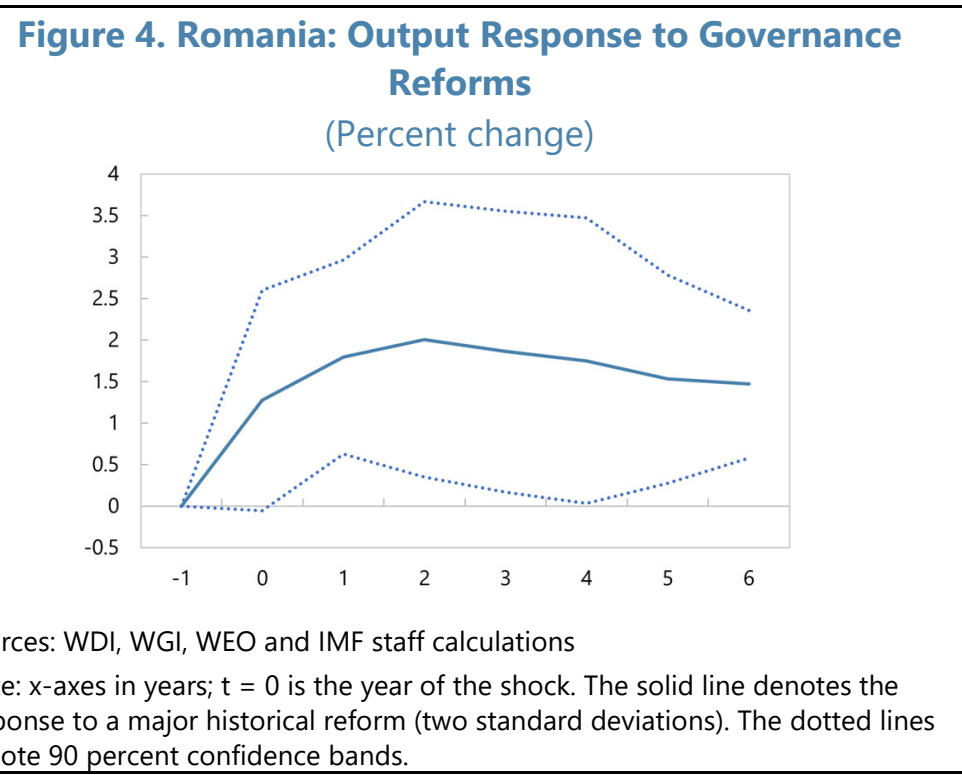

Table 1. Romania: Regression Results for the Impact of Governance Reforms on Output

\begin{tabular}{lccccc}
\hline VARIABLES & $(1)$ & $(2)$ & $(3)$ & $(4)$ & $(5)$ \\
\hline & $y_{t}-y_{t-1}$ & $y_{t+1}-y_{t-1}$ & $y_{t+2}-y_{t-1}$ & $y_{t+3}-y_{t-1}$ & $y_{t+4}-y_{t-1}$ \\
GovShock & 0.0602 & $0.0848^{* *}$ & $0.0949^{*}$ & $0.0879^{*}$ & 0.0828 \\
& $(0.0381)$ & $(0.0336)$ & $(0.0477)$ & $(0.0486)$ & $(0.0494)$ \\
L1.GovShock & 0.0252 & 0.0284 & 0.0150 & 0.0213 & 0.0257 \\
& $(0.0155)$ & $(0.0260)$ & $(0.0263)$ & $(0.0351)$ & $(0.0295)$ \\
L2.GovShock & 0.0137 & 0.00162 & -0.00105 & 0.00280 & 0.00833 \\
& $(0.0185)$ & $(0.0183)$ & $(0.0257)$ & $(0.0246)$ & $(0.0312)$ \\
L1.GDP_growth & -0.00105 & -0.000392 & 0.000276 & 0.00246 & 0.000920 \\
& $(0.00145)$ & $(0.00130)$ & $(0.00161)$ & $(0.00175)$ & $(0.00197)$ \\
L2.GDP_growth & $0.000644^{* *}$ & $0.00145^{* *}$ & 0.00132 & -0.000396 & $-0.00193^{*}$ \\
& $(0.000271)$ & $(0.000538)$ & $(0.00106)$ & $(0.000799)$ & $(0.000892)$ \\
Observa tions & 1,390 & 1,389 & 1,295 & 1,201 & 1,107 \\
Number of \\
countries
\end{tabular}


11. These estimation results suggest that a feasible governance reform effort in Romania would significantly boost medium-term growth prospects. A reform scenario, motivated by the pace of governance reforms observed during the EU accession period, ${ }^{6}$ suggests that closing $1 / 2$ of the governance gap with the EU peers by 2026 (see Figure 5) would increase annual medium-term output growth rate by $0.3 \mathrm{pp}$. The persistent reform effort would close $1 / 4$ of Romania's income gap with its EU peers by 2026, increasing its GDP level by 2.7 percent.

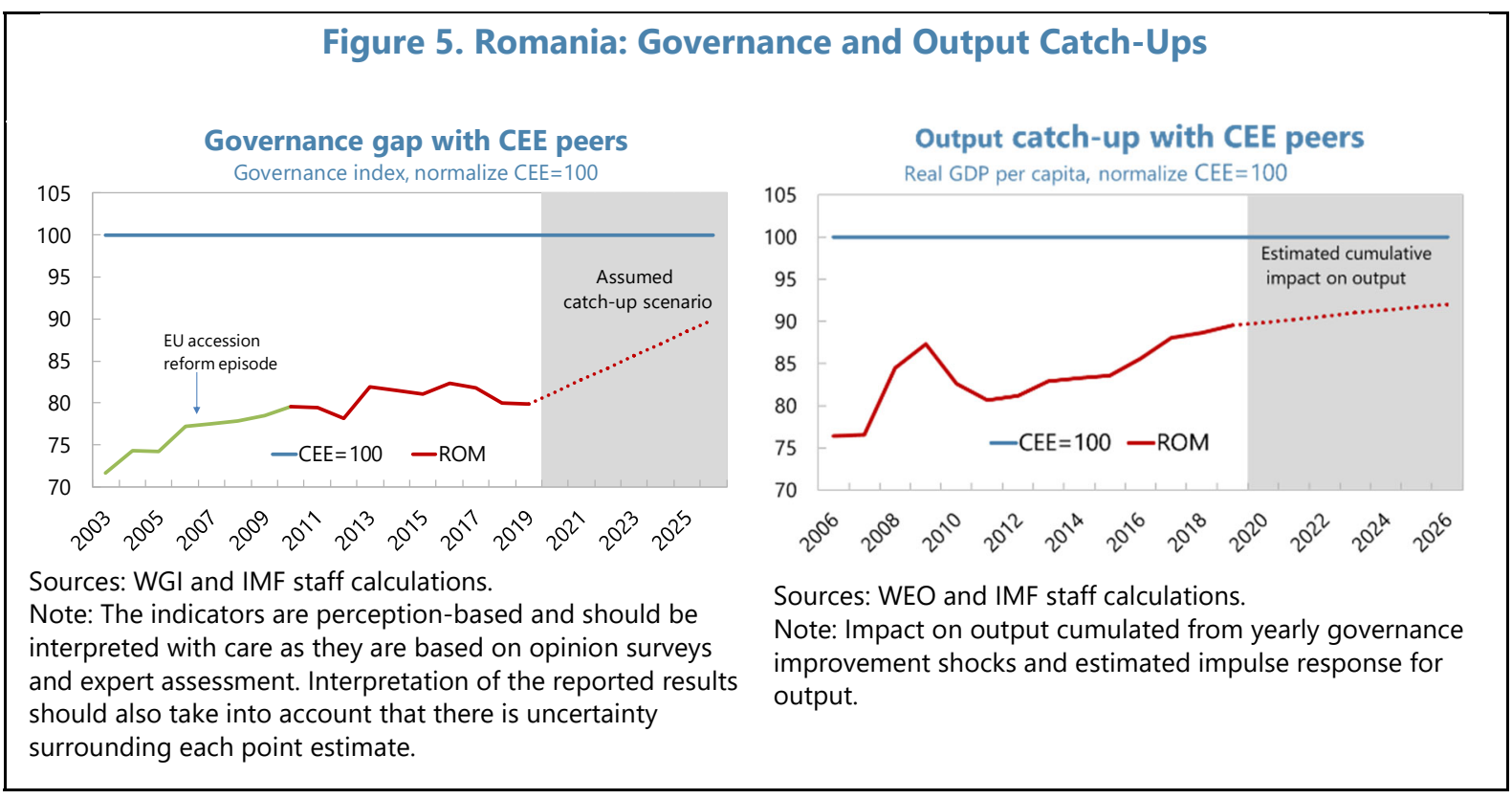

12. The impact could be even larger if reforms target gains in government effectiveness, where the gap with peers is the largest. Among the subindices we used to construct the governance index, government effectiveness (see Annex II. for detailed definition) shows the largest potential for increasing output. Figure 6 plots the output responses to a two standard deviation shock in government

Figure 6. Romania: Output Response to Government Effectiveness Reforms (Percent change)

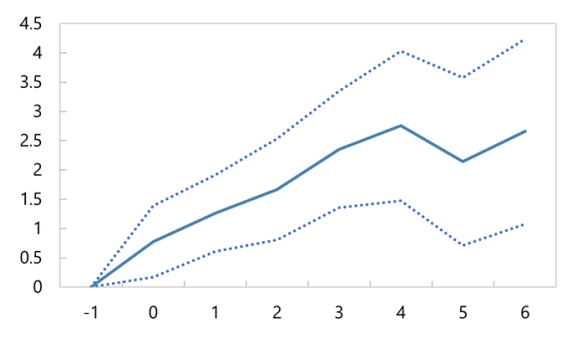

Sources: WDI, WGI, WEO and IMF staff calculations.

Note: $\mathrm{x}$-axes in years; $\mathrm{t}=0$ is the year of the shock. The solid line denotes the response to a major historical reform (two standard deviations). The dotted lines denote 90 percent confidence bands.

\footnotetext{
${ }^{6}$ The implied pace of reforms for this scenario-a 0.45 standard deviations increase in the governance index per year-is broadly consistent with the progress observed during the EU accession period (2003-2010), which saw a 0.42 standard deviation increase per year. The impact on output is calculated as the accumulation from yearly governance improvement shocks, using the impulse response shown in Figure 4
} 
effectiveness, one of the subindices used to construct the governance index. The impact on output from reforms in government effectiveness is persistent and larger than for the broader index. As already shown in Figure 4, output increases by $1.5 \%$ as a response to the shock to the overall constructed index at a 6-year horizon. The output response to an improvement in government effectiveness almost doubles this number. The response to higher regulatory quality shows a similar pattern as for the overall index, while the response to strengthening the rule of law is less significant and diminishes at a 6-year horizon (see Figure 7).

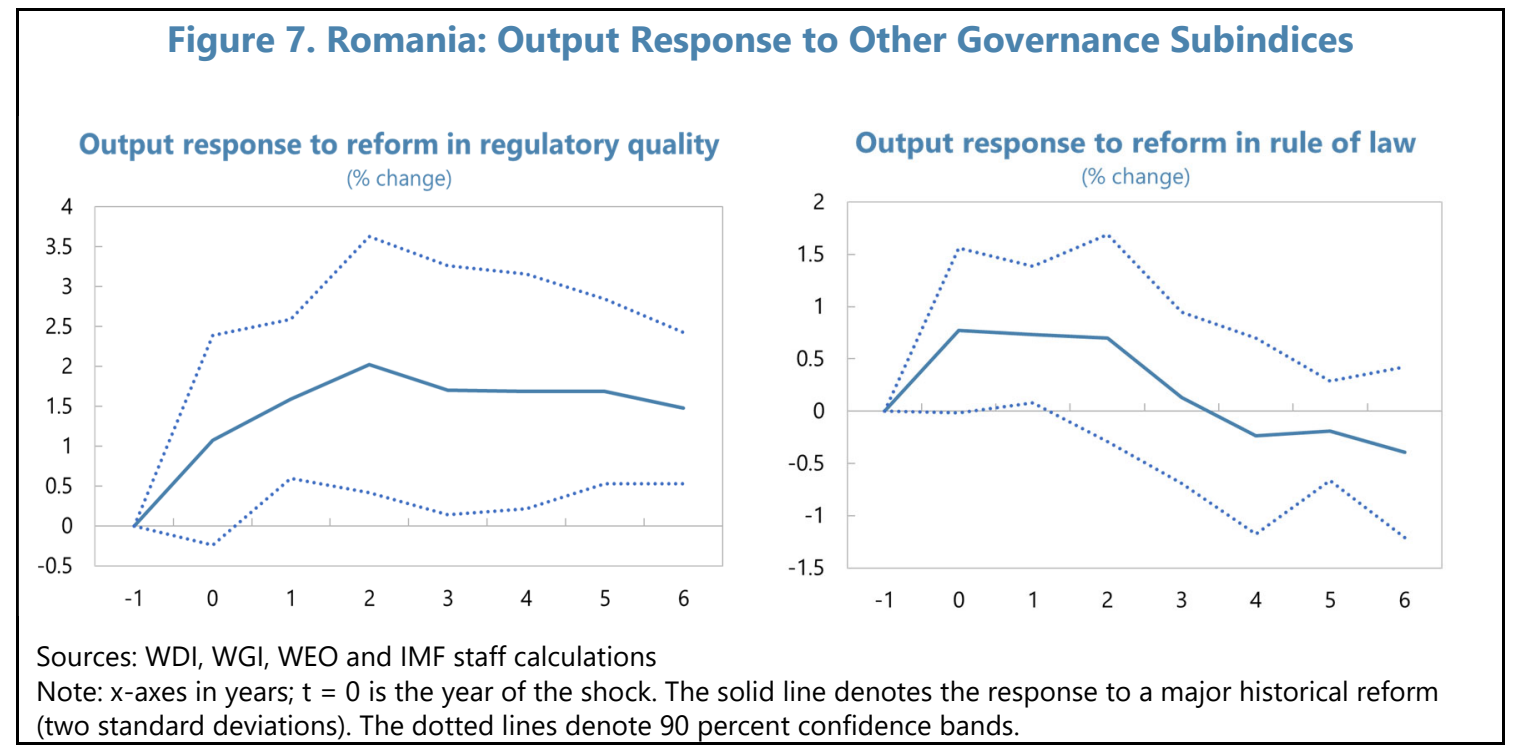

\section{The Role of the Investment Channel}

\section{To shed more light on the impact of governance on output, we study the role of} investment as a transmission channel. Regression results (from equation (1)) suggest that both public investment and private investment respond positively and significantly to shocks in governance (see Table 2 and Table 3), with the increase in private investment being more persistent in the medium term (see Figure 8). The impacts reach peak levels for public investment 3 years after the shock, and 1 year after the shock for private investment. Regression results from the outputinvestment equation (i.e., equation (2)) are in line with Furceri and Li, suggesting that output responds positively and significantly to investment shocks-a 10 percent increase in public investment increases output by 0.2-0.4 percent depending on the horizon, and similar results apply to an increase in private investment (see Table 4, Table 5 and Figure 9).

\section{Based on the results from regression equation (2) in Table 4, we infer that the short-} term fiscal multiplier is $\mathbf{0 . 4 5}$ and the medium-term fiscal multiplier is $\mathbf{0 . 8 5}$. A 10 percent increase in the public investment increases output by 0.23 percent on impact and 0.42 percent in a 3 -year horizon. Considering that on average, public investment is 5 percent of GDP, the fiscal multiplier can be calculated. We consider the short-run multiplier to be in line with the literature, 
Table 2. Romania: Regression Results for the Impact of Governance Reforms on Public Investment

\begin{tabular}{|c|c|c|c|c|c|}
\hline \multirow[b]{2}{*}{ Public Investment } & (1) & (2) & (3) & (4) & (5) \\
\hline & $y_{t}-y_{t-1}$ & $y_{t+1}-y_{t-1}$ & $y_{t+2}-y_{t-1}$ & $y_{t+3}-y_{t-1}$ & $y_{t+4}-y_{t-1}$ \\
\hline \multirow[t]{2}{*}{ GovShock } & $0.583^{* *}$ & $0.804 * * *$ & $1.012 * * *$ & $1.108 * * *$ & $0.749 *$ \\
\hline & $(0.237)$ & $(0.222)$ & $(0.223)$ & $(0.295)$ & $(0.380)$ \\
\hline \multirow[t]{2}{*}{ L1.GovShock } & $0.438 * * *$ & $0.644 * * *$ & $0.657 * * *$ & $0.486^{*}$ & $0.680 * * *$ \\
\hline & $(0.0963)$ & $(0.168)$ & $(0.199)$ & $(0.233)$ & $(0.209)$ \\
\hline \multirow[t]{2}{*}{ L2.GovShock } & $0.424 * * *$ & $0.431 * * *$ & 0.156 & $0.385^{*}$ & 0.391 \\
\hline & $(0.0976)$ & $(0.136)$ & $(0.227)$ & $(0.212)$ & $(0.249)$ \\
\hline \multirow[t]{2}{*}{ L1.GDP_growth } & 0.00151 & 0.00277 & 0.00276 & 0.00548 & 0.00602 \\
\hline & $(0.00197)$ & $(0.00308)$ & $(0.00488)$ & $(0.00494)$ & $(0.00541)$ \\
\hline \multirow[t]{2}{*}{ L2.GDP_growth } & -0.000651 & 0.00468 & 0.00400 & 0.00323 & -0.00766 \\
\hline & $(0.00212)$ & $(0.00335)$ & $(0.00334)$ & $(0.00450)$ & $(0.00539)$ \\
\hline \multirow[t]{2}{*}{ L1.PubInv } & $-0.225 * * *$ & $-0.283 * * *$ & $-0.351 * * *$ & $-0.302 * * *$ & $-0.295 * *$ \\
\hline & $(0.0472)$ & $(0.0712)$ & $(0.0572)$ & $(0.0910)$ & (0.0989) \\
\hline \multirow[t]{2}{*}{ L2. PubInv } & -0.0450 & $-0.273 * * *$ & $-0.194 * * *$ & $-0.241 * *$ & -0.120 \\
\hline & $(0.0618)$ & $(0.0409)$ & $(0.0616)$ & $(0.0869)$ & $(0.128)$ \\
\hline Observations & 545 & 544 & 502 & 461 & 420 \\
\hline Number of countries & 42 & 42 & 42 & 42 & 42 \\
\hline
\end{tabular}

Table 3. Romania: Regression Results for the Impact of Governance Reforms on Private Investment

\begin{tabular}{|c|c|c|c|c|c|}
\hline Priv a te Investment & $\begin{array}{c}(1) \\
y_{t}-y_{t-1}\end{array}$ & $\begin{array}{c}(2) \\
y_{t+1}-y_{t-1}\end{array}$ & $\begin{array}{c}(3) \\
y_{t+2}-y_{t-1}\end{array}$ & $\begin{array}{c}(4) \\
y_{t+3}-y_{t-1}\end{array}$ & $\begin{array}{c}(5) \\
y_{t+4}-y_{t-1}\end{array}$ \\
\hline Gov Shock & $\begin{array}{c}0.409 \\
(0.326)\end{array}$ & $\begin{array}{c}0.922 * * * \\
(0.192)\end{array}$ & $\begin{array}{c}0.826 * * * \\
(0.227)\end{array}$ & $\begin{array}{c}0.679^{* *} \\
(0.273)\end{array}$ & $\begin{array}{l}0.768^{*} \\
(0.356)\end{array}$ \\
\hline L1. Gov Shock & $\begin{array}{c}0.602 * * * \\
(0.191)\end{array}$ & $\begin{array}{c}0.513 * * * \\
(0.114)\end{array}$ & $\begin{array}{c}0.528 * * \\
(0.191)\end{array}$ & $\begin{array}{c}0.449^{* *} \\
(0.182)\end{array}$ & $\begin{array}{c}0.939 * * * \\
(0.212)\end{array}$ \\
\hline L2. Gov Shock & $\begin{array}{c}0.0418 \\
(0.0951)\end{array}$ & $\begin{array}{l}0.0384 \\
(0.116)\end{array}$ & $\begin{array}{l}0.0675 \\
(0.216)\end{array}$ & $\begin{array}{c}0.265^{* *} \\
(0.116)\end{array}$ & $\begin{array}{c}0.421 * * * \\
(0.0956)\end{array}$ \\
\hline L1.GDP_growth & $\begin{array}{l}-0.00119 \\
(0.00427)\end{array}$ & $\begin{array}{l}-0.00410 \\
(0.00553)\end{array}$ & $\begin{array}{l}-0.0153^{*} \\
(0.00739)\end{array}$ & $\begin{array}{l}-0.00573 \\
(0.00684)\end{array}$ & $\begin{array}{l}-0.00205 \\
(0.00313)\end{array}$ \\
\hline L2.GDP_growth & $\begin{array}{l}-0.0111 * * \\
(0.00415)\end{array}$ & $\begin{array}{l}-0.0115^{*} \\
(0.00588)\end{array}$ & $\begin{array}{l}-0.00410 \\
(0.00798)\end{array}$ & $\begin{array}{c}-0.00967^{*} \\
(0.00507)\end{array}$ & $\begin{array}{c}-0.0163 * * * \\
(0.00478)\end{array}$ \\
\hline L1. PrivInv & $\begin{array}{c}-0.393^{* * *} \\
(0.0940)\end{array}$ & $\begin{array}{c}-0.354 * * \\
(0.140)\end{array}$ & $\begin{array}{c}-0.536^{* * *} \\
(0.128)\end{array}$ & $\begin{array}{c}-0.353 * * \\
(0.142)\end{array}$ & $\begin{array}{c}-0.653 * * * \\
(0.115)\end{array}$ \\
\hline L2. PrivInv & $\begin{array}{c}0.0693 \\
(0.0792)\end{array}$ & $\begin{array}{c}-0.240 * * \\
(0.110)\end{array}$ & $\begin{array}{r}-0.0701 \\
(0.135)\end{array}$ & $\begin{array}{l}-0.184 \\
(0.127)\end{array}$ & $\begin{array}{c}-0.287^{*} \\
(0.146)\end{array}$ \\
\hline Observations & 518 & 518 & 478 & 438 & 399 \\
\hline Number of countries & 40 & 40 & 40 & 40 & 40 \\
\hline
\end{tabular}


Figure 8. Romania: Investment Response to Governance Reforms
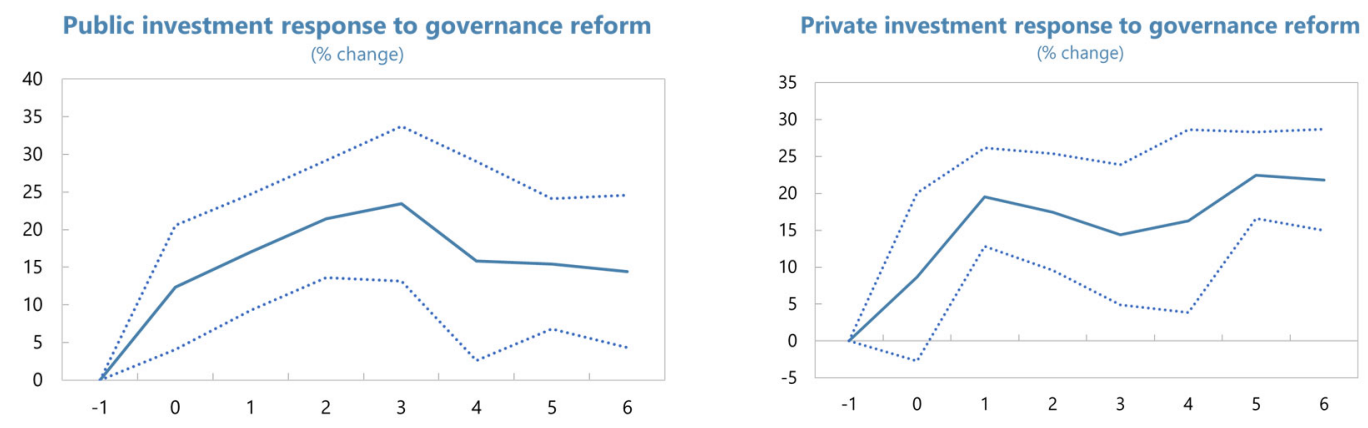

Sources: WDI, WGI, WEO and IMF staff calculations.

Note: $\mathrm{x}$-axes in years; $\mathrm{t}=0$ is the year of the shock. The solid line denotes the response to a major historical reform (two standard deviations). The dotted lines denote 90 percent confidence bands.

Table 4. Romania: Regression Results for the Impact of Public Investment on Output

\begin{tabular}{lccccc}
\hline & $(1)$ & $(2)$ & $(3)$ & $(4)$ & $(5)$ \\
VARIABLES & $y_{t}-y_{t-1}$ & $y_{t+1}-y_{t-1}$ & $y_{t+2}-y_{t-1}$ & $y_{t+3}-y_{t-1}$ & $y_{t+4}-y_{t-1}$ \\
\hline & & & & & \\
PubInvShock & $0.0225^{* *}$ & $0.0339^{* * *}$ & $0.0345^{* *}$ & $0.0423^{* *}$ & $0.0398^{*}$ \\
& $(0.00856)$ & $(0.0117)$ & $(0.0152)$ & $(0.0175)$ & $(0.0203)$ \\
L1.PubInvShock & 0.00466 & 0.00369 & 0.00934 & 0.00594 & 0.000420 \\
& $(0.00315)$ & $(0.00729)$ & $(0.0117)$ & $(0.0133)$ & $(0.0158)$ \\
L2.PubInvShock & -0.00337 & -0.00866 & -0.0212 & -0.0295 & $-0.0328^{*}$ \\
& $(0.00246)$ & $(0.00907)$ & $(0.0139)$ & $(0.0173)$ & $(0.0165)$ \\
L1.GDP_growth & $0.00384 * * *$ & $0.00464^{* * *}$ & $0.00569^{* * *}$ & $0.00646^{* * *}$ & $0.00601^{* *}$ \\
& $(0.000567)$ & $(0.00111)$ & $(0.00149)$ & $(0.00200)$ & $(0.00218)$ \\
L2.GDP_growth & 0.000495 & $0.00304^{* *}$ & $0.00417^{* *}$ & $0.00401 *$ & $0.00390^{*}$ \\
& $(0.000392)$ & $(0.00125)$ & $(0.00181)$ & $(0.00205)$ & $(0.00227)$ \\
& & & & & \\
Observa tions & 1,683 & 1,605 & 1,527 & 1,450 & 1,374 \\
Number of countries & 78 & 78 & 78 & 78 & 72 \\
\hline Note: Standard errors (a symptotic Driscoll-Kra ay SEs are used) are in parentheses. $* * * \mathrm{p}<0.01, * * \mathrm{p}<0.05, * \mathrm{p}<0.1$.
\end{tabular}

while the medium-term estimate is on the conservative side. Furceri and Li 2017 find the fiscal multiplier to be 0.2 in the short-run and 0.6 at a 5-year horizon. Ramey 2019 argues that most of the literature has found fiscal multipliers to be below 1 . However, the author also points out that larger multipliers could arise in economic downturns (e.g. ZLB) or for investment-specific spending. Blanchard and Leigh 2012 find the short-run fiscal multiplier to be 0.9 to 1.7 for European countries during recession periods. A survey of infrastructure investment multipliers by Ramey 2021 concludes that short-run multiplies can be significantly below 1, while long-run investment multipliers can be significantly larger than 1. For the purpose of this study, it is important to note that while the estimated multipliers determine the size of the investment channel in transmitting the impact of governance reforms on output growth, it does not affect the estimated overall impact of governance reforms on output growth. 
Table 5. Romania: Regression Results for the Impact of Private Investment on Output

\begin{tabular}{|c|c|c|c|c|c|}
\hline & (1) & (2) & (3) & (4) & (5) \\
\hline VARIABLES & $y_{t}-y_{t-1}$ & $y_{t+1}-y_{t-1}$ & $y_{t+2}-y_{t-1}$ & $y_{t+3}-y_{t-1}$ & $y_{t+4}-y_{t-1}$ \\
\hline \multirow{2}{*}{ PrivInvShock } & $0.0156^{* * *}$ & $0.0295^{* * *}$ & $0.0396^{* * *}$ & $0.0455^{* * *}$ & $0.0414 * * *$ \\
\hline & $(0.00441)$ & $(0.00657)$ & $(0.0107)$ & $(0.0136)$ & $(0.0139)$ \\
\hline \multirow[t]{2}{*}{ L1. PrivInvShock } & $0.00975^{*}$ & $0.0220 * *$ & $0.0259^{*}$ & 0.0205 & 0.0206 \\
\hline & $(0.00528)$ & $(0.0107)$ & $(0.0141)$ & $(0.0150)$ & $(0.0157)$ \\
\hline \multirow[t]{2}{*}{ L2. PrivInvShock } & $0.0116^{* *}$ & $0.0162 *$ & 0.00997 & 0.00721 & 0.0168 \\
\hline & $(0.00437)$ & $(0.00798)$ & $(0.00957)$ & $(0.00920)$ & $(0.0111)$ \\
\hline \multirow[t]{2}{*}{ L1.GDP_growth } & $0.00393^{* * *}$ & $0.00470 * * *$ & $0.00571 * * *$ & $0.00641 * * *$ & $0.00586 * *$ \\
\hline & $(0.000549)$ & $(0.00111)$ & $(0.00154)$ & $(0.00205)$ & $(0.00218)$ \\
\hline \multirow[t]{3}{*}{ L2.GDP_growth } & 0.000348 & $0.00277 * *$ & $0.00377^{*}$ & 0.00362 & 0.00355 \\
\hline & $(0.000412)$ & $(0.00125)$ & $(0.00187)$ & $(0.00217)$ & $(0.00240)$ \\
\hline & $(0.00140)$ & $(0.00325)$ & $(0.00659)$ & $(0.00545)$ & $(0.0119)$ \\
\hline Observations & 1,638 & 1,563 & 1,488 & 1,413 & 1,339 \\
\hline Number of groups & 75 & 75 & 75 & 75 & 69 \\
\hline
\end{tabular}

Figure 9. Romania: Output Response to Investment Shocks

Output response to a $10 \%$ public investment shock Output response to a $10 \%$ private investment shock (\% change) (\% change)
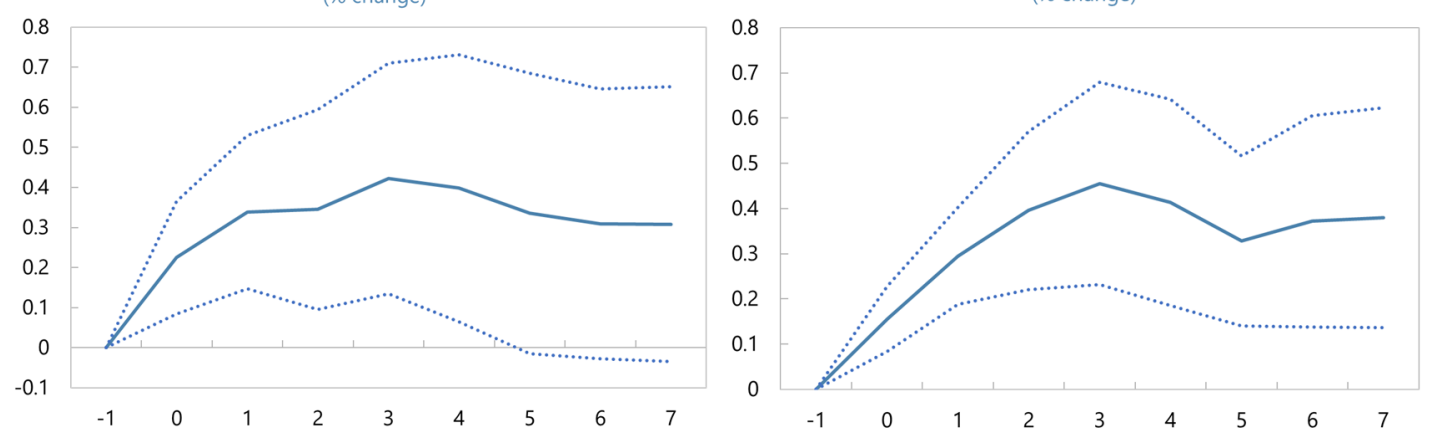

Sources: WDI, WGI, WEO and IMF staff calculations.

Note: $x$-axes in years; $t=0$ is the year of the shock. The solid line denotes the response to a major historical reform (two standard deviations). The dotted lines denote 90 percent confidence bands. 
15. The results suggest that investment is the main channel of transmission of improvements in governance to output. To determine the contribution of the investment channel under the reform scenario, we first consider the increases in output (see Table 1) and in public and private investment (see Tables 2 and 3) due to governance shocks by using regression equation (1), and then calculate the increase in output that is induced by the increase in investment based on regression equation (2) (see Tables 4 and 5). We find that public and private investment channels each account for about $1 / 3$ of the total increase in output under

Figure 10. Romania: Infrastructure Response to Governance Reforms

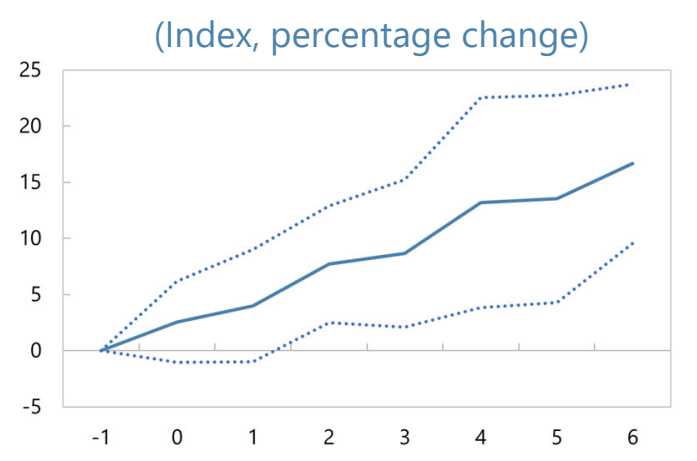

Sources: WDI, WGI, WEO and IMF staff calculations.

Note: $x$-axes in years; $t=0$ is the year of the shock. The solid line denotes the response to a major historical reform (two standard deviations). The dotted lines denote 90 percent confidence bands.

the reform scenario. ${ }^{7}$ Governance reforms can also boost output through other channels, including the labor channel. For example, while emigration has decreased labor productivity in Romania as skilled people have been leaving, better governance can help retain these workers and thus have a positive impact on output by increasing human capital (Cooray and Schneider 2016). We also note that the positive impact of governance reforms is not limited to output. Our analysis and previous literature suggest that governance reforms are positively linked with a reduction in inequality (see annex III) and informality (2019 October WEO Chapter 3).

\section{E. Bridging the Infrastructure Gap}

16. Governance reforms could also help with the infrastructure catchup between Romania and peer countries. To measure the impact of governance reforms on the infrastructure stock, we first construct an infrastructure index out of several indicators, as a summary measure for the infrastructure level of the country. Four infrastructure indicators are used: internet usage (percent of population), air passengers carried (passengers carried per population), mobile usage (percent of population) and rail track density (kilometer per thousand hectare). These series are standardized first, as they are in different units. Then common information is extracted by using the Principal Component Analysis (PCA) to form a single indicator (the first principal component). The regression results, based on equation (1), suggest that this infrastructure indicator responds positively and significantly to governance reforms. (see Figure 10 and Table 6). Under the reform scenario, Romania would close 61 percent of the infrastructure gap with CEE peers by 2026. (see Figure 11).

\footnotetext{
${ }^{7}$ Given that our long-run fiscal multiplier is estimated on the conservative side relative to the literature, we note that a higher multiplier would increase the role of the public investment channel.
} 
Figure 11. Romania: Infrastructure Catch-Up with CEE Peers

(Index, normalize CEE $=100$ )

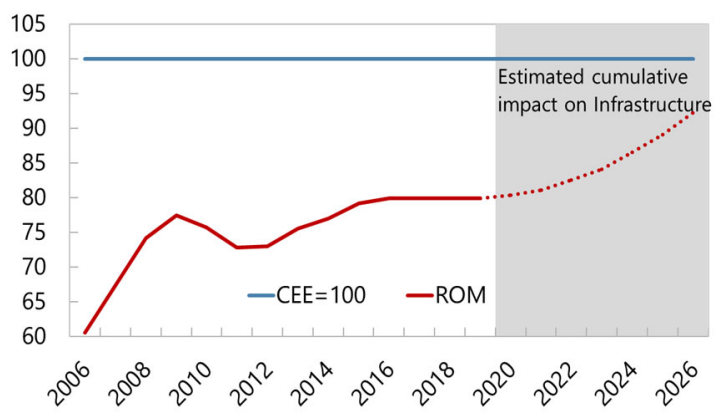

Sources: WDI and IMF staff calculations.

Note: Infrastructure index is constructed out of four infrastructure indicators. We aggregate the impacts on infrastructure from each year's governance catchup shock based on the regression results to calculate the infrastructure index increase for a certain year.

Table 6. Romania: Regression Results for the Impact of Governance Reforms on Infrastructure Index

\begin{tabular}{|c|c|c|c|c|c|}
\hline & (1) & (2) & (3) & (4) & (5) \\
\hline Infrastructure Index & $y_{t}-y_{t-1}$ & $y_{t+1}-y_{t-1}$ & $y_{t+2}-y_{t-1}$ & $y_{t+3}-y_{t-1}$ & $y_{t+4}-y_{t-1}$ \\
\hline \multirow[t]{2}{*}{ GovShock } & 0.121 & 0.189 & $0.364 * *$ & $0.409 * *$ & $0.623 * *$ \\
\hline & $(0.104)$ & $(0.143)$ & $(0.149)$ & $(0.188)$ & $(0.268)$ \\
\hline \multirow[t]{2}{*}{ L1.GovShock } & 0.0381 & $0.211 *$ & $0.355^{*}$ & $0.472 *$ & $0.569 * *$ \\
\hline & $(0.0532)$ & $(0.113)$ & $(0.182)$ & $(0.266)$ & $(0.213)$ \\
\hline \multirow[t]{2}{*}{ L2.GovShock } & $0.196 * *$ & $0.274 *$ & $0.519 * *$ & $0.515 * *$ & $0.720 * *$ \\
\hline & $(0.0872)$ & $(0.147)$ & $(0.228)$ & $(0.212)$ & $(0.243)$ \\
\hline \multirow{2}{*}{ L1.GDP_growth } & 0.00312 & 0.00698 & $0.0112 * *$ & $0.0177 * * *$ & $0.0221 * * *$ \\
\hline & $(0.00297)$ & $(0.00416)$ & $(0.00497)$ & $(0.00532)$ & $(0.00527)$ \\
\hline \multirow[t]{2}{*}{ L2.GDP_growth } & 0.00180 & 0.00578 & $0.0102 * *$ & $0.0126^{* * *}$ & $0.0114^{* * *}$ \\
\hline & $(0.00152)$ & $(0.00341)$ & $(0.00378)$ & $(0.00338)$ & $(0.00368)$ \\
\hline \multirow[t]{2}{*}{ L1.infra_index } & $0.212 * *$ & $0.353 * *$ & $0.546 * * *$ & $0.624 * * *$ & $0.696^{*}$ \\
\hline & $(0.0716)$ & $(0.129)$ & $(0.182)$ & $(0.200)$ & $(0.330)$ \\
\hline \multirow{2}{*}{ L2.infra_index } & $0.133 * *$ & 0.182 & 0.0977 & -0.0227 & -0.279 \\
\hline & $(0.0491)$ & $(0.114)$ & $(0.160)$ & $(0.313)$ & $(0.499)$ \\
\hline Observations & 394 & 379 & 365 & 334 & 304 \\
\hline Number of countries & 40 & 37 & 33 & 32 & 32 \\
\hline
\end{tabular}




\section{F. Conclusions and Policy Recommendations}

\section{Efforts to improve economic governance need to be re-energized in Romania.}

Empirical evidence for EMs confirms that governance improvements can have a significant positive impact on output. Applying these estimates to Romania, we find that bridging half of the gap in governance rankings with regional peers could add 0.3 percentage points annually to Romania's medium-term growth. Persistent reform efforts could close $1 / 4$ of Romania's income gap with its EU peers by 2026. The main channel of impact involves public and private investment, each accounting for $1 / 3$ of the total impact on output. Furthermore, governance improvements could also help alleviate social challenges such as migration, inequality and informality.

\section{To maximize medium-term growth prospects, improving government effectiveness} should be a key focus of the governance reform agenda. This is the area of governance where gaps with regional peers are the widest. Furthermore, empirical estimates show that gains in government effectiveness have the largest output impact among governance sub-components investigated. Given the centrality of the investment channel in generating output gains, improvements in public investment management should be a priority, covering all aspects from the planning stage to more efficient procurement to speed-up project implementation. SOE performance is another area in need of improvements. Governance of SOEs needs to be strengthened, which will help boost public investment and accelerate the absorption of EU funds. Consistent implementation of corporate governance reforms and improved monitoring of SOE financial performance would be important reform components. While the main discussion of the paper focuses on the impact on growth, reforms in other areas of governance could be favored if needed for other policy targets. 


\section{Annex I. List of EM Countries and Data Sources}

\section{List of Countries}

\begin{tabular}{|l|l|l|}
\hline Albania & Georgia & Peru \\
\hline Algeria & Grenada & Philippines \\
\hline Angola & Guatemala & Poland, Rep. of \\
\hline Antigua and Barbuda & Guyana & Qatar \\
\hline Argentina & Hungary & Romania \\
\hline Armenia & India & Russia \\
\hline Azerbaijan & Indonesia & Samoa \\
\hline Bahamas, The & Iran & Saudi Arabia \\
\hline Bahrain & Iraq & Serbia \\
\hline Barbados & Jamaica & Seychelles \\
\hline Belarus, Rep. of & Jordan & South Africa \\
\hline Belize & Kazakhstan & Sri Lanka \\
\hline Bosnia and Herzegovina & Kosovo, Rep. of & St. Kitts and Nevis \\
\hline Botswana & Kuwait & St. Lucia \\
\hline Brazil & Lebanon & St. Vincent and the Grenadines \\
\hline Brunei Darussalam & Libya & Suriname \\
\hline Bulgaria & Lithuania & Syria \\
\hline Cabo Verde & Malaysia & Thailand \\
\hline Chile & Maldives & Timor-Leste, Dem. Rep. of \\
\hline China & Marshall Islands, Rep. of the & Trinidad and Tobago \\
\hline Colombia & Mauritius & Tonga \\
\hline Costa Rica & Mexico & Tunisia \\
\hline Croatia & Micronesia, Federated States of & Turkey \\
\hline Dominica & Montenegro, Rep. of & Turkmenistan \\
\hline Dominican Republic & Morocco & Tuvalu \\
\hline Ecuador & Namibia & Ukraine \\
\hline Egypt & North Macedonia, Republic of & United Arab Emirates \\
\hline El Salvador & Oman & Uruguay \\
\hline Equatorial Guinea & Pakistan & Vanuatu \\
\hline Eswatini & Palau & Venezuela \\
\hline Fiji, Rep. of & Panama & \\
\hline Gabon & Paraguay & \\
\hline & & \\
\hline
\end{tabular}

CInternational Monetary Fund. Not for Redistribution 


\section{Data Sources}

1) IMF WEO Database

2) World Bank World Development Index (WDI)

3) Worldwide Governance Index (WGI) by Daniel Kaufmann and Aart Kraay

4) Eurostat 


\section{Annex II. Definition of Worldwide Governance Index}

1. Government Effectiveness: Reflects perceptions of the quality of public services, the quality of the civil service and the degree of its independence from political pressures, the quality of policy formulation and implementation, and the credibility of the government's commitment to such policies.

2. Regulatory Quality: Reflects perceptions of the ability of the government to formulate and implement sound policies and regulations that permit and promote private sector development.

3. Rule of Law: Reflects perceptions of the extent to which agents have confidence in and abide by the rules of society, and in particular the quality of contract enforcement, property rights, the police, and the courts, as well as the likelihood of crime and violence.

4. Voice and Accountability: Reflects perceptions of the extent to which a country's citizens are able to participate in selecting their government, as well as freedom of expression, freedom of association, and a free media.

5. Political Stability and Absence of Violence/Terrorism: Reflects perceptions of the likelihood that the government will be destabilized or overthrown by unconstitutional or violent means, including politically-motivated violence and terrorism.

6. Control of Corruption: Reflects perceptions of the extent to which public power is exercised for private gain, including both petty and grand forms of corruption, as well as "capture" of the state by elites and private interests. 


\section{Annex III. Governance and Inequality}

1. Governance reforms could also reduce inequality, as measured using the Gini index for disposable income taken from the Standardized World Income Inequality Database (SWIID). The higher the Gini index is, the more inequality the country has. Regression results suggest that the Gini index does respond negatively and significantly to governance improvements based on the same set of sample countries as in the main text (see charts and table below). Under the reform scenario we defined in section C, Romania's Gini index would be reduced by 3.1 percent by 2026, closing 55 percent of the inequality gap with CEE peers. This is calculated by measuring the impact of governance reforms on the level of Gini index using the regression equation (1).

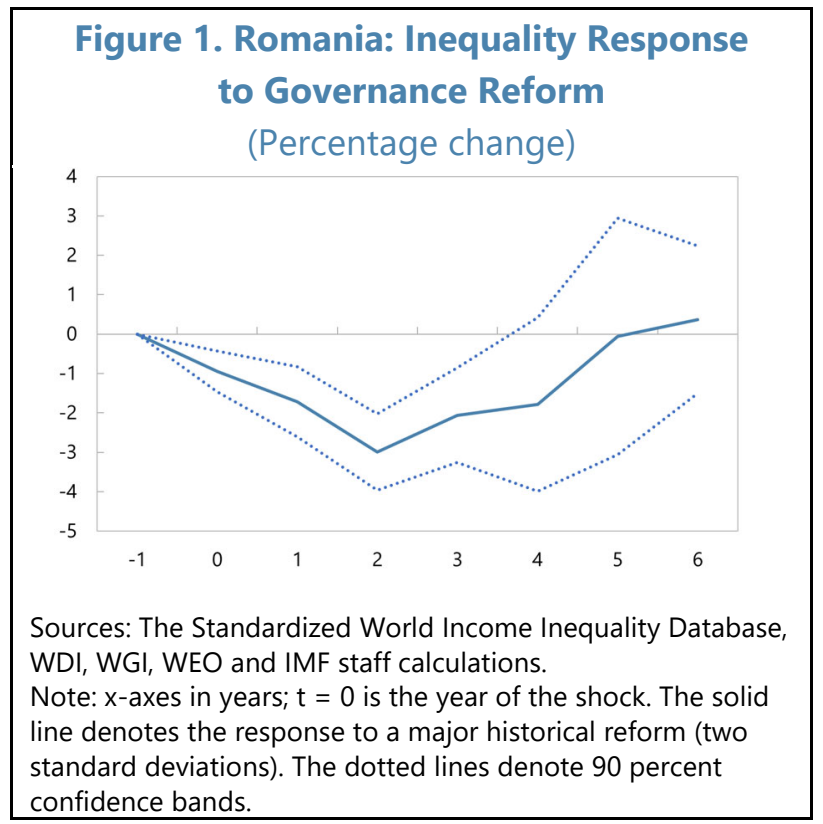

Figure 2. Romania: Gini Index Catchup

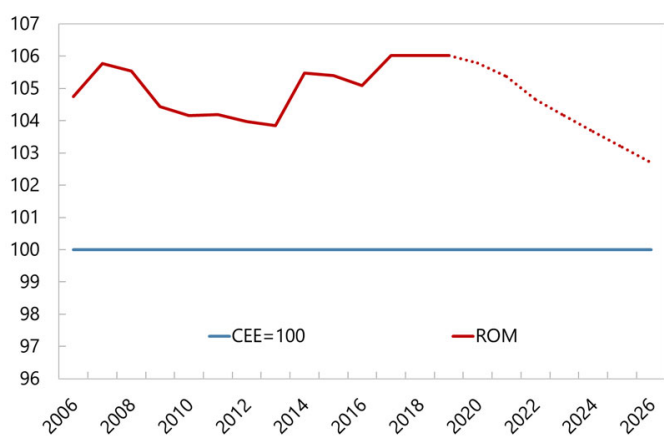

Sources: The Standardized World Income Inequality Database and IMF staff calculations. 
Table 1. Romania: Regression Results for the Impact of Governance Reforms on Gini Index

\begin{tabular}{|c|c|c|c|c|c|}
\hline & (1) & (2) & (3) & (4) & (5) \\
\hline Gini index & $y_{t}-y_{t-1}$ & $y_{t+1}-y_{t-1}$ & $y_{t+2}-y_{t-1}$ & $y_{t+3}-y_{t-1}$ & $y_{t+4}-y_{t-1}$ \\
\hline GovShock & $\begin{array}{l}-0.0446^{* \star} \\
(0.0149)\end{array}$ & $\begin{array}{l}-0.0811^{* *} \\
(0.0256)\end{array}$ & $\begin{array}{l}-0.141^{\star \star *} \\
(0.0277)\end{array}$ & $\begin{array}{c}-0.0971 * * \\
(0.0345)\end{array}$ & $\begin{array}{l}-0.0842 \\
(0.0635)\end{array}$ \\
\hline L1.GovShock & $\begin{array}{l}-0.0112 \\
(0.0178)\end{array}$ & $\begin{array}{l}-0.0300 \\
(0.0237)\end{array}$ & $\begin{array}{l}-0.0408 \\
(0.0478)\end{array}$ & $\begin{array}{l}0.00528 \\
(0.0399)\end{array}$ & $\begin{array}{c}0.0882^{* * *} \\
(0.0249)\end{array}$ \\
\hline L2.GovShock & $\begin{array}{l}-0.0261^{\star *} \\
(0.0117)\end{array}$ & $\begin{array}{l}-0.0383 \\
(0.0235)\end{array}$ & $\begin{array}{l}0.00682 \\
(0.0375)\end{array}$ & $\begin{array}{l}0.102^{* *} \\
(0.0312)\end{array}$ & $\begin{array}{l}0.0942 * \\
(0.0439)\end{array}$ \\
\hline L1.GDP_growth & $\begin{array}{c}0.00157^{\star} \\
(0.000716)\end{array}$ & $\begin{array}{l}0.00243^{*} \\
(0.00114)\end{array}$ & $\begin{array}{c}0.00242 \\
(0.00193)\end{array}$ & $\begin{array}{l}-0.000182 \\
(0.000568)\end{array}$ & $\begin{array}{l}3.71 \mathrm{e}-06 \\
(0.000520)\end{array}$ \\
\hline L2.GDP_growth & $\begin{array}{c}0.000914^{\star *} \\
(0.000392)\end{array}$ & $\begin{array}{l}0.00122^{\star *} \\
(0.000514)\end{array}$ & $\begin{array}{c}0.000771 \\
(0.000716)\end{array}$ & $\begin{array}{l}0.000956 \\
(0.00101)\end{array}$ & $\begin{array}{l}0.000950 \\
(0.00108)\end{array}$ \\
\hline L1.Gini & $\begin{array}{l}0.200 * * * \\
(0.0556)\end{array}$ & $\begin{array}{c}0.586^{\star * *} \\
(0.164)\end{array}$ & $\begin{array}{l}0.0842 \\
(0.268)\end{array}$ & $\begin{array}{l}-0.101 \\
(0.169)\end{array}$ & $\begin{array}{l}-0.316 \\
(0.308)\end{array}$ \\
\hline L2.Gini & $\begin{array}{l}0.316^{\star * *} \\
(0.0395)\end{array}$ & $\begin{array}{l}-0.0402 \\
(0.0997)\end{array}$ & $\begin{array}{l}-0.165 \\
(0.209)\end{array}$ & $\begin{array}{l}-0.336 \\
(0.275)\end{array}$ & $\begin{array}{l}-0.689 * \star \\
(0.265)\end{array}$ \\
\hline $\begin{array}{l}\text { Observations } \\
\text { Number of countries }\end{array}$ & $\begin{array}{c}537 \\
62\end{array}$ & $\begin{array}{c}475 \\
60\end{array}$ & $\begin{array}{c}415 \\
60\end{array}$ & $\begin{array}{c}355 \\
60\end{array}$ & $\begin{array}{c}295 \\
58\end{array}$ \\
\hline $\begin{array}{l}\text { Note: Standard errors } \\
\text { effects are included b }\end{array}$ & $\begin{array}{l}\text { tic Driscoll- } \\
\text { wn. }\end{array}$ & Es are use & arenthe & $<0.01,{ }^{* *} p$ & ${ }^{*} p<0.1$. Fixec \\
\hline
\end{tabular}




\section{References}

Blanchard, O., \& Leigh, D. 2013. Growth Forecast Errors and Fiscal Multipliers. The American Economic Review, 103(3), 117-120.

Cooray, Arusha and Schneider, Friedrich. (2016). Does corruption promote emigration? An empirical examination, Journal of Population Economics, 29, issue 1, p. 293-310.

Furceri, Davide and Li, Bin (Grace). 2015. The Macroeconomic (and Distributional) Effects of Public Investment in Developing Economies, IMF Working Paper No. 17/217.

Ramey, Valerie A. 2019. Ten Years after the Financial Crisis: What Have We Learned from the Renaissance in Fiscal Research? Journal of Economic Perspectives, 33 (2): 89-114.

Ramey, Valerie A. 2021. The Macroeconomic Consequences of Infrastructure Investment. CEPR Discussion Paper No. DP15998

IMF. 2017. Regional Economic Outlook for Europe, November.

IMF. 2018. Review of 1997 Guidance Note on Governance-A Proposed Framework for Enhanced Fund Engagement. Policy Paper, April

IMF. 2019. Fiscal Monitor, April.

IMF. 2019. Romania: 2019 Article IV Consultation.

IMF. 2019, World Economic Outlook, October.

IMF. 2021, World Economic Outlook, April 2021.

IMF. 2020, EUR Departmental Paper No.20/11 